\title{
Market Orientation and Customer Point of View - In The Case Of Azerbaijan
}

\author{
Dr. Shahin AKBAROV \\ Faculty of Turkish World of Business Administration, Economy and Business \\ Administration, Azerbaijan State University of Economics / UNEC, Baku, Azerbaijan
}

\begin{abstract}
Purpose: The research aimed to investigate how consumers percept marketing activities of firms in Azerbaijan, within the framework of market orientation phenomenon described by Narver and Slater.

Methodology: 333 questionnaires were gained through convenience sample. Data was analyzed with SPSS 24. Confirmatory factor analysis was first done and then regression analysis.

Findings: According to the results of research, items relate to MKTOR assembled into two factors: customer orientation and competitor orientation. Only customer orientation have significant positive effect on customer satisfaction and customer trust.

Originality: The study is important because it is carried out in Azerbaijan, a country which is new in market economy. Although marketing concept is not new phenomenon for western country, for Azerbaijan it is new, as country lived in planned economy till 1991. The results of the research are thought to be beneficial to both the theorists and the practitioners.
\end{abstract}

KEYWORDS: Market Orientation, Customer Orientation, Competitor Orientation, Customer Trust, Customer Satisfaction, MKTOR, Azerbaijan.

\section{Introduction}

The most discussed views in the market orientation literature are the views of "Kohli and Jaworski" and "Narver and Slater". The general opinion is that these two views are not opposite or different, but rather complementary (Matsuno et al., 2005; Griffiths and Grover, 1998; Cadogan and Diamantopoulos, 1995; Gray et al., 1998; Bigne et al., 2003).

Pelham (1993) stated that Kohli and Jaworski's market orientation construct is insufficient to measure market orientation. Thus, according to Pelham (1993), understanding and responding to customer needs is more than information analysis and deciding on the basis of this knowledge. In addition, the spread of information across the organization does not enable the customer to be understood at the organization level and to behave market-oriented at the organization level. On the contrary, Pelham stated that Narver and Slater's MKTOR scale can explain customer value proposition by measures such as customer satisfaction, after-sales services and top management's communication with customers. 
The MKTOR scale, consisting of 15 elements, indicates that the customer is the main element of the market orientation and firms should be responsible to the customer across the organization.

\section{Literature Review}

Narver and Slater (1994) argue that market orientation consists of three elements: customer orientation, competitor orientation, inter-functional coordination.

\subsection{Customer Orientation}

Narver and Slater (1994) point out that customer orientation is the heart of market orientation. Customer orientation is constantly recognizing existing and potential target customers and creating customer value in the light of this information (Narver and Slater, 1990). To offer what the customer wants, firms i) must know what the customers want, ii) must know how much they value the different things they want, iii) make offerings that overlap with the customer's desires, and iv) inform customers (Oxenfeldt and Moore, 1978). Foss and Stone (2001: 306) defined customer orientation as the ability to view things from a customer perspective.

\subsection{Competitor Orientation}

Competitor orientation is the recognizing the capability and strategies of the main and potential companies that are constantly serving the target market of the firm, and using this knowledge to create superior customer value (Narver and Slater, 1990). Competitor orientation requires identifying the company's competitors first, then gathering information about the goals, strategies, strengths and weaknesses and reaction patterns of these competitors.

Competitor orientation sees market as the fight between firms for marketing rewards (Oxenfeldt and Moore, 1978).

\subsection{Inter-functional Coordination}

Inter-functional coordination is the coordination of all business activities in order to benefit from customer and other market information to create superior customer value (Narver and Slater, 1990). The literature suggests three ways to achieve effective inter-functional coordination (Tay and Tay, 2007). First, the performance goals of the functional departments are determined by emphasizing the market (customer satisfaction). Second, it is the creation of the inter-functional linkage that enables functions to pursue their own interests when they cooperate with other functions. The third way is the necessity of the functions to be highly sensitive and responsible to the needs of other functions (Tay and Tay, 2007).

\subsection{Market Orientation and Customer Perspective}

In the market orientation literature, there is a general trend in which market orientation is assessed from the point of view of business people. However, some researchers (Webb et al., 2000; Steinman et al., 2000; Abu Bakar et al., 2005; Krepapa et al., 2003; Hashim and Abu Bakar, 2008; Mulyanegara, 2010) stated that it would be more appropriate to assess market orientation from the consumer's perspective. Research that focuses on external dynamics (employees and consumer relations) rather than focusing on internal dynamics (relationships between organization and employees) offers a more beneficial perspective on the market orientation outcome (Chen and Quester, 2009).

According to Steinman et al. (2000), a sufficient level of market orientation is what customers think regarding what it should be. Webb et al. (2000) argue that the customer`s perspective on measuring market orientation is more important, that of the organizational point of view taht points out only one aspect of the situation, and that it can result in a myopic evaluation, thus ignoring the customer role that is crucial to value perception. If the relationship between market orientation and customer satisfaction is measured from a customer's point of view, it becomes 
more appropriate. Because customers who view business as highly market-oriented are likely to be more satisfied (Webb et al., 2000).

In their research on business in Japan, Deshpande et al. (1993) found no significant relationship between business performance and perception of firms regarding its customer orientation, but there was a positive link between business performance and perception of customers regarding customer orientation of the firms. Donavan and Hocutt (2001) found that there is a positive relationship between the opinions of restaurant customers about customer-oriented behaviors of restaurant employees and customer satisfaction, and customer loyalty. Corbitt et al. (2003) conclude that higher perceived market orientation results in higher levels of perceived trust.

Analyzes of customer perceptions related to market orientation show that it is applicable to customers by reducing and changing well-known market orientation measurement instruments (Webb et al., 2000).

\subsection{Customer Trust}

Trust is defined as the willingness of one partner to rely on a change partner (Moorman et al., 1992, Act., Moorman et al., 1993) and the belief in the partner's honesty and charity (Bigne and Blesa, 2003). Customer trust will be positively affected by the customer orientation of the vendors (Bejou et al., 1998).

\subsection{Customer Satisfaction}

In this research, customer satisfaction is considered as the satisfaction of customers from product quality and prices. In the literature, the positive effect of market orientation on customer satisfaction is emphasized (Kohli and Jaworski, 1990, Kirca et al., 2005, O'Cass and Ngo, 2009).

\section{Research Model and Hypotheses}

As a result of the literature review, the following model (Figure 1) has been adopted and hypotheses have been developed for testing.

\section{Figure 1. Research Model}

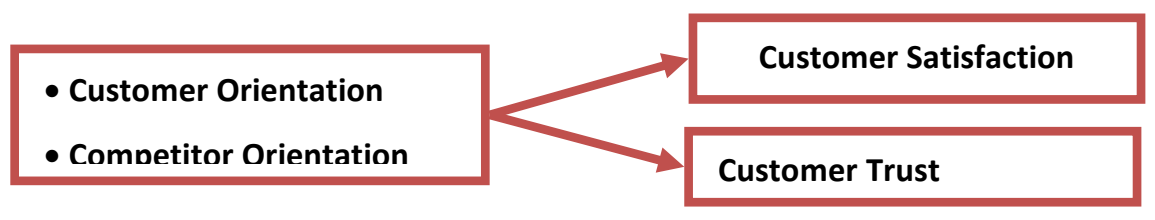

H 1. Customer orientation has positive impact on customer satisfaction

H 2. Customer orientation has positive impact on customer trust

H 3. Competitor orientation has positive impact on customer satisfaction

H 4. Competitor orientation has positive impact on customer trust 


\section{Methodology}

For the research, the MKTOR scale developed by Narver and Slater (1990) is considered. Two items were canceled from the original MKTOR scale. In order to measure customer satisfaction, two questions were asked: "Customers are satisfied with the price and quality of products". Items measuring customer trust are adapted from Langerak (2001) and include three items: "Companies are sincere with us", " We trust the promises of companies", "Companies are on our side".

The items were translated into Azerbaijani language and after the approval of the language and marketing experts, pilot study were conducted with 20 respondents. Then, 333 questionnaires were collected using convenience sampling method. The universe of research is Baku population over 18 years old.

The questionnaire consists of demographic questions, market orientation scale (MKTOR) and items that measure customer satisfaction and customer trust. All items were measured on a fivepoint Likert type scale where 1 representing "strongly disagree" and 5 "strongly agree". The data were analyzed with the SPSS 24.

\section{Analyzes and Findings}

Some socio-demographic characteristics of the sample are presented in Table 1.

Table 1. Socio-demographic characteristics of the sample

\begin{tabular}{|c|c|c|c|}
\hline Variable & Category & Number & Percent \\
\hline \multirow{2}{*}{ Gender } & Male & 239 & 71,8 \\
\hline & Female & 94 & 28,2 \\
\hline \multirow{3}{*}{ Age } & $18-25$ & 156 & 46,8 \\
\hline & $26-36$ & 88 & 26,5 \\
\hline & $37+$ & 89 & 26,7 \\
\hline \multirow{5}{*}{ Education } & High school & 33 & 9,9 \\
\hline & College & 28 & 8,4 \\
\hline & Undergraduate & 204 & 61,3 \\
\hline & Master & 49 & 14,7 \\
\hline & Doctorate & 19 & 5,7 \\
\hline \multirow{4}{*}{ Monthly Income } & Low income & 139 & 41,7 \\
\hline & Low-middle income & 125 & 37,6 \\
\hline & Middle income & 48 & 14,4 \\
\hline & MIddle - high income & 21 & 6,3 \\
\hline \multicolumn{2}{|c|}{ Total } & 333 & 100,0 \\
\hline
\end{tabular}




\section{Factor Analysis}

As a result of the reliability analysis measured by Cronbach's Alpha coefficient, the reliability of the scale was found to be 0,90 . In order to determine the dimensions of market orientation, 13 items were subjected to factor analysis. Two dimensions were determined after the analysis. The results of factor analysis are given in Table 2.

Table 2. Factor Analysis

\begin{tabular}{|c|c|c|c|}
\hline \multicolumn{4}{|l|}{ KMO $=0,908$, Bartlett, $d f=78, p<0,001$} \\
\hline Factor & $\begin{array}{c}\text { Factor } \\
\text { Load }\end{array}$ & $\begin{array}{c}\% \text { of } \\
\text { Variance }\end{array}$ & $\begin{array}{l}\text { Cronbach's } \\
\text { Alpha }\end{array}$ \\
\hline Customer Orientation & & 29,67 & $\mathbf{0 , 8 5}$ \\
\hline $\begin{array}{l}\text { I think that managers from all departments of firms are } \\
\text { visiting customers }\end{array}$ & 0,77 & & \\
\hline After-sales service of firms are good & 0,77 & & \\
\hline $\begin{array}{l}\text { I think that firms measure customer satisfaction } \\
\text { systematically }\end{array}$ & 0,71 & & \\
\hline $\begin{array}{l}\text { I think that information regarding customer } \\
\text { experiences are sharing among firms functions }\end{array}$ & 0,66 & & \\
\hline $\begin{array}{l}\text { I think that all the functions of the firms are integrated } \\
\text { for serving the needs of the market }\end{array}$ & 0,65 & & \\
\hline $\begin{array}{l}\text { Managers of firms know how their employees will } \\
\text { benefit a customer }\end{array}$ & 0,60 & & \\
\hline The purpose of the firms is to satisfy customers & 0,54 & & \\
\hline Competitor Orientation & & 24,77 & $\mathbf{0 , 8 2}$ \\
\hline $\begin{array}{l}\text { Firms are targeted to customers who can create a } \\
\text { competitive advantage }\end{array}$ & 0,74 & & \\
\hline $\begin{array}{l}\text { I think that firms share competitor information within } \\
\text { the firm }\end{array}$ & 0,73 & & \\
\hline Firms commit to customer needs & 0,70 & & \\
\hline Firms respond quickly to competitive trends & 0,61 & & \\
\hline Firms`strategies are tailored to customer needs & 0,59 & & \\
\hline $\begin{array}{l}\text { I think that the top management of the firms regularly } \\
\text { discusses the strategies of the competitors }\end{array}$ & 0,58 & & \\
\hline Total Variance Explained & & $\mathbf{5 4 , 4 4}$ & \\
\hline
\end{tabular}




\section{Market Orientation and Customer Satisfaction}

In order to determine the effect of market orientation elements on customer satisfaction, elements of market orientation are included as independent variables and customer satisfaction is included as a dependent variable in regression analysis. As a result of the regression analysis, it is found that the model which implies the effect of the independent variables, market orientation factors, on the dependent variable, customer satisfaction, is statistically significant: $F=159,689, p<0,001$.

Table 3. Results of regression analysis for the market orientation elements and customer satisfaction

\begin{tabular}{|c|c|c|c|c|c|c|}
\hline \multicolumn{7}{|c|}{ Coefficients $^{\mathrm{a}}$} \\
\hline \multirow{2}{*}{\multicolumn{2}{|c|}{ Model }} & & $\begin{array}{l}\text { Unstandardized } \\
\text { Coefficients }\end{array}$ & $\begin{array}{l}\text { Standardized } \\
\text { Coefficients }\end{array}$ & \multirow[b]{2}{*}{$\mathrm{t}$} & \multirow[b]{2}{*}{ Sig. } \\
\hline & & B & Adjusted R Square & Beta & & \\
\hline \multirow[t]{3}{*}{1} & (Constant) & -.090 & \multirow{3}{*}{0.488} & & -.491 & .624 \\
\hline & Customer Orientation & .964 & & .732 & 13.188 & .000 \\
\hline & Competitor Orientation & -.062 & & -.045 & -.810 & .419 \\
\hline \multicolumn{7}{|c|}{ a. Dependent Variable: Customer Satisfaction } \\
\hline
\end{tabular}

According to the results of the regression analysis, only customer orientation has a significant effect on customer satisfaction. Although the effect of competitor orientation on customer satisfaction is very low and negative, this effect was not found to be significant according to the results of the regression analysis.

Market orientation elements explain $48.8 \%$ of customer satisfaction. In other words, $48.8 \%$ of the change in customer satisfaction is due to the market orientation measured by the MKTOR scale.

The stepwise regression method was used to determine the explanatory nature of the elements of the market orientation on customer satisfaction. When we look at the explanatory power of the components at separate, we see that the competition orientation does not contribute to the model, whereas the customer orientation component explains $49 \%$ of the dependent variable. When customer orientation goes up by 1 , customer satisfaction goes up by 0,964 (B). The effect of constant and competitor orientation is not statistically significant ( $\mathrm{p}=0.624>0.05 ; \mathrm{p}=0.429>0.05$ ).

\section{Market Orientation and Customer Trust}

In order to determine the effect of market orientation elements on customer trust, elements of market orientation are included as independent variables and customer trust is included as a dependent variable in regression analysis. As a result of the regression analysis, it is found that the model which implies the effect of the independent variables, market orientation factors, on the dependent variable, customer trust, is statistically significant: $F=181,798, p<0,001$. 
Tablo 4. Results of regression analysis for the market orientation elements and customer trust

\begin{tabular}{|c|c|c|c|c|c|c|}
\hline \multicolumn{7}{|c|}{ Coefficients $^{\mathrm{a}}$} \\
\hline \multirow{2}{*}{\multicolumn{2}{|c|}{ Model }} & \multicolumn{2}{|c|}{ Unstandardized Coefficients } & \multirow{2}{*}{$\begin{array}{c}\text { Standardized } \\
\text { Coefficients } \\
\text { Beta }\end{array}$} & \multirow[b]{2}{*}{$\mathrm{t}$} & \multirow{3}{*}{$\begin{array}{l}\text { Sig. } \\
.402\end{array}$} \\
\hline & & B & $\begin{array}{c}\text { Adjusted R } \\
\text { Square }\end{array}$ & & & \\
\hline 1 & (Constant) & -.147 & \multirow{3}{*}{0.521} & & -.839 & \\
\hline & Customer Orientation & 1.021 & & .783 & 14.581 & .000 \\
\hline & $\begin{array}{l}\text { Competitor } \\
\text { Orientation }\end{array}$ & -.119 & & -.088 & -1.635 & .103 \\
\hline
\end{tabular}

According to the results of the regression analysis, only customer orientation has a significant effect on customer trust. Although the effect of competitor orientation on customer trust is very low and negative, this effect was not found to be significant according to the results of the regression analysis.

Market orientation elements explain $52.1 \%$ of customer trust. In other words, $52.1 \%$ of the change in customer trust is due to the market orientation measured by the MKTOR scale.

The stepwise regression method was used to determine the explanatory nature of the elements of the market orientation on customer trust. When we look at the explanatory power of the components at separate, we see that the competition orientation does not contribute to the model, whereas the customer orientation component explains $52 \%$ of the dependent variable. When customer orientation goes up by 1 , customer trust goes up by 1,021 (B). The effect of constant and competitor orientation is not statistically significant $(\mathrm{p}=0.402>0.05 ; \mathrm{p}=0.103>0.05)$.

\section{Conclusions}

In this study, the items of MKTOR scale were subjected to factor analysis in order to determine the dimensions related to market orientation in the perception of consumers.

As a result of the factor analysis, the items of the MKTOR scale are collected in two dimensions: Customer Orientation and Competitive Orientation. Although Narver and Slater have shown that the third dimension is the coordination dimension, the dimension of coordination has not appeared separately in our research.

The effect of two market orientation dimensions on customer satisfaction and customer trust were examined seperately.

According to the analysis, customer orientation has a high level of explanatory power on customer satisfaction and customer trust (49\% and 52\% respectively). Competitor orientation has no any explanatory power on customer satisfaction and customer trust.

Customer orientation has a high and significant effect on customer satisfaction and customer trust $(\mathrm{B}=0.964 ; \mathrm{B}=1.021$ respectively). Thus hypothesis $\mathrm{H} 1$ and $\mathrm{H} 2$ was supported. Competitor orientation has no effect on customer satisfaction and customer trust Thus hypothesis H3 and H4 were rejected. 
The fact that the only customer orientation has a statistically significant effect on customers can lead us to conclude that the market orientation of the firms in Azerbaijan can be measured by customer orientation if we want to access its performance effect. There may be some reasons why competitor orientation is not effective. First, it may be due to the low competitive environment in Azerbaijan. Second, customers may not be concerned that a firm is competitor-oriented and they may be concerned only to what extent do firms care about them. Third, there is a common belief among the people of Azerbaijan that competition can lead to monopoly. Because competing firm wants to defeat competitor, rather than to serve better than a competitor. However, in developed Western economies (at least in Western marketing literature), being competitor-oriented means that they will be able to serve customer on more favorable terms by examining the competitor.

This research supports the idea that market orientation can be measured as customer orientation orientation (Deshpande et al., 1993) and measuring of competitor and customer orientation under one construct is not right (Sörensen, 2009). Zhao and Cavusgil (2006) found that the customer orientation of the supplier was influential on the buyer's trust, but there was no significant relationship between the supplier's competitor orientation and the buyer's trust. In this regard, the results of our research are consistent with the research undertaken.

If competitor orientation includes serving better than competitors, it can be assessed under the same construct with customer orientation, as market orientation. If competitor orientation relies on the philosophy of taking the share of competitors and wiping them out of the market (or if customers perceive that), it would be wrong to consider this concept under the same construct with the customer focus.

The results of the research indicate that in Azerbaijan, a transition economy, it may be more appropriate to approach the market orientation as customer orientation.

\section{References}

ABU BAKAR, A.R., S.S. Mohd Mokhtar ve A.F.A. Fizri (2005), An Application of a CustomerDefined Market Orientation: Antecedents and Consequences, Asia Pacific Marketing Conference, Malaysia, ss. 22-24.

BEJOU, David, Christine T. Ennew ve Adrian Palmer (1998), Trust, ethics and relationship satisfaction, International Journal of Bank Marketing, Vol.16, No.4, ss. 170-175.

BIGNE, Enrique ve Andreu Blesa (2003), Market Orientation, Trust And Satisfaction İn Dyadic Relationships: A Manufacturer-Retailer Analysis, International Journal of Retail \& Distribution Management, Vol. 31, No. 11, ss. 574-590.

BIGNE, E, I. Kuster ve F. Toran (2003), "Market Orientation and Industrial Salesforce: Diverse Measure Instruments," Journal of Business and Industrial Marketing, Vol. 18, No.1, ss. 59-81.

CADOGAN J. W. ve A. Diamantopoulos (1995), Narver and Slater, Kohli and Jaworski and The Market Orientation Construct: Integration and Internationalization, Journal of Strategic Marketıng, No. 3, ss. 41-60.

CORBITT, B.J., T. Thanasankit ve H. Yi (2003), Trust and e-Commerce: A Study Of Consumer Perceptions, Electronic Commerce Research and Applications, Vol. 2, ss. 203-215.

DESHPANDE, R., J.U. Farley ve F. Webster (1993), "Corporate Culture, Customer Orientation, and Innovativeness in Japanese Firms: A Quadrad Analysis", Journal of Marketing, Vol. 57, No. 1, ss. 23-37. 
DONAVANA, D.T. ve M. Ann Hocutt (2001), Customer Evaluation Of Service Employee's Customer Orientation: Extension and Application, Journal of Quality Management, Vol. 6, ss. 293-306.

FOSS, B. ve M. Stone (2001), Successful Customer Relationship Marketing: New Thinking, New Strategies, New Tools For Getting Closer To Your Customers, Kogan Page, London/Milford.

GRAY, B., S. Matear, C. Boshoff ve P. Matheson (1998), Developing A Better Measure Of Market Orientation, European Journal of Marketing, Vol. 32, No. 9/10, ss. 884-903.

GRIFFITHS, J. S. ve R. Grover (1998), A Framework For Understanding Market Orientation: The Behavior And The Culture, In D. Grewal, \& C. Pechman (Eds.), Marketing Theory and Applications, Vol. 9, ss. 311-320.

KIRCA Ahmet H., Satish Jayachandran ve William O. Bearden (2005), Market Orientation: A Meta-Analytic Review and Assessment of Its Antecedents and Impact on Performance, Journal of Marketing, Vol. 69, ss. 24-41.

KOHLI, Ajay. ve Bernard. J. Jaworski (1990), Market Orientation: The Construct, Research Propositions, and Managerial Implications, Journal of Marketing, Vol. 54, ss. 1-18.

KREPAPA, A., Berthon, P., Webb, D. ve L. Pitt (2003), "Mind The Gap: An Analysis Of Service Provider Versus Customer Perceptions Of Market Orientation And The İmpact On Satisfaction", European Journal of Marketing, Vol. 37 No. 1/2, ss.197-218.

LANGERAK, F. (2001), Effects Of Market Orientation On The Behaviors Of Salespersons And Purchasers, Channel Relationships, And Performance Of Manufacturers, International Journal of Research in Marketing, Vol. 18, ss. 221-234.

MATSUNO, Ken, John T. Mentzer ve J.O. Rentz (2005), A Conceptual and Empirical Comparison of Three Market Orientation Scales, Journal of Business Research, 58 (1), ss. 1-8.

MOORMAN, Christine, Rohit Deshpandé ve Gerald Zaltman (1993), Factors Affecting Trust in Market Research Relationships, The Journal of Marketing, Vol. 57, No.1, ss. 81-101.

NARVER, John ve Stanley Slater (1990), The Effect of Market Orientation on Business Profitability, Journal of Marketing, Vol. 54, No. 4, ss. 20-35.

O'CASS, Aron ve Liem Ngo (2009), Achieving Customer Satisfaction Via Market Orientation, Brand Orientation, And Customer Empowerment: Evidence From Australia, ANZMAC.

OXENFELDT, A.R. ve W.L. Moore (1978), "Customer or Competitor: Which Guideline for Marketing?," Management Review, ss. 43-48.

PELHAM, AM (1993), Mediating and Moderating İnfluences On The Relationship Between Market Orientation and Performance, Doctoral dissertation, Pennsylvania State University.

SLATER, Stanley F. ve John C. Narver (1994), Market Orientation, Customer Value and Superior Performance, Business Horizons, March-April, ss. 22-28.

SÖRENSEN, H. E. (2009), Why Competitors Matter For Market Orientation, European Journal of Marketing, Vol. 43 No. 5/6, ss. 735-761. 
STEINMAN, C., R. Deshpande ve J. Farley (2000), Beyond Market Orientation: When Customers and Suppliers Disagree, Journal of the Academy of Marketing Science, Vol.28, No.1, ss, 109119.

TAY, Jasmine Y.W. ve Linda Tay (2007), Market Orientation and Property Development Business in Singapore, International Journal of Stratejic Property Management, Vol. 11, ss. $1-16$.

WEBB, D., C. Webster ve A. Krepapa (2000), An Exploration of The Meaning and Outcomes of a Customer-Defined Market Orientation, Journal of Business Research, Vol. 48, ss. 101-112.

ZHAO, Yushan ve S. Tamer Cavusgil (2006), The Effect Of Supplier's Market Orientation On Manufacturer's Trust, Industrial Marketing Management, Vol. 35, ss. 405 - 414. 